Biannual Research Journal Grassroots

Vol.55, No.I, 2021: 173-185

Grassroots

\title{
DOMESTIC VIOLENCE AGAINST FEMALE BEGGARS IN HYDERABAD DISTRICT: A CASE STUDY QASIMABAD
}

\author{
Syeda Qurat ul Ain Shah \\ Ph.D Scholar, Department of Sociology, University of Sindh Jamshoro \\ Email: ainneeshah@gmail.com \\ Dr. Parveen Shah \\ Professor of Economics \& Ex-Vice Chancellor Shah Abdul Latif University, Khairpur \\ Dr. Aijaz Ali Wassan \\ Professor Department of Sociology, University of Sindh, Jamshoro \\ Email: aijaz.wassan@usindh.edu.pk
}

\begin{abstract}
This Paper analyses the causes of the domestic violence against female beggars and their impacts on their lives. The paper is strictly limited to Taluka Qasimabad, District Hyderabad. The domestic violence against women exits in various forms. However, it is pretty horrible in the form being inflicted against female beggars in Qasimabad. The scores of causes for the domestic violence against female beggars range from rising poverty to population explosions with deep physical and mental impacts on the sufferers. For data collection qualitative research through Focused Group discussion method has been used through snow ball technique. 10 Cases of female beggars have been opted for the FGDs out of which two participated with their social backgrounds.

The study concludes the pathetic condition of the female beggars due to multiple factors and their serious implications both physically as well as mentally. The study recommends prompt action from the Government as well as social scientist to go deep further in the social issues such as violence against the female beggars. Simultaneously there is immediate intervention of Government and the concerned department to address these issues on emergent basis as the number is likely to reach an alarming level.
\end{abstract}

Keywords: Domestic violence, Female beggars, Qasimabad

\section{INTRODUCTION}

Although man has touched the skies and made incredible advancements in the field of science and technology, the condition of women continues to remain far from good mainly in Pakistan. Social and electronic media spare significant portions for the women where the conditions of women are portrayed at length. Women are still persecuted, tortured and bruised by the men. Numerous studies bear 
witness that majority of domestic violence sufferer are women in all around the world. They face increasingly extreme types of violence (McQuigg et.al., 2011 and Garcia et.al., 2013). Violence against female beggars has been a hot issue over the years. It has been extrapolated from the surveys that there is a significant relation between level of gender equality and domestic violence; nations having less gender equality encounter higher percentage of domestic violence (Esquivel et.al., Jan 2013). Similarly, it is observed that supplication of beggar women is limited till money, food and shelter, so, vulnerability towards violence is all because of extreme poverty. In this way, beggars in street are more disrespected and dishonored, because, to have their status penniless and homeless suffer lots of indignities just for the sake of sparing life. The indignities such as, both physical and verbal abuse from the passers-by (Fawole et.al., 2013). Women face extremely hostile behavior since their childhood, they go on to face particularly depression, poor physical including mental health, which directly affect their lives of children and wellbeing of society is to be threatened (Lombard \& Mcmillan, 2013). Discrimination occurs due to low economic and social status, rising poverty various norms and some sort of rules of family that create hindrances for women to leave for job (Shahid, 2004). Inequality and discrimination is imparted to women since their birth and older women remain silent victim, oppressed and violated that is the virtue given by their family and society as well (Fikree and Pasha, 2004).

The review of the past researches highlights that globally domestic violence is among such crimes which are largely unreported (Bryan et.al., Feb 16, 2010 and Diana, July 11, 2013).

The reviews of the past studies mention the high statistics of domestic violence in Pakistan. Parveen et.al., state that domestic violence has become order of the day which happens within a family as usual. In Pakistani society, discrimination faced by women is very common which is all because of cultural and religious norms. The analysis reveals 72 to $90 \%$ women in Pakistan experience domestic violence which includes mental, physical and emotional abuse. When the survey over 1000 women was conducted in Punjab, 35\% of them were hospitalized by admitting that they had been beaten violently by their husband. 
With this perception, it comes to image the reflection of extensive cultural structure in which men are valued to be dominated by justifying the violence in order to maintain their superiority over women (Zakar, Zakar \& Kraemer, 2013). Moreover, with regard to context of Pakistani community, this intimate partner violence has been functioned as means for maintaining the respect by using abusive language behavior so as to demonstrate wife is merely just nothing but men's subordinate (Zakar et.al., 2013). Physical abuse, is not a unique, it is as usual perception in culture of Pakistan,. In this regard when women are asked about abuse they frequently responded with argument a physical abuse (Aslam, Zaheer, \& Shafique, 2015).

Furthermore, noting down the official report on Karo-Kari, 28 hundred women have been murdered by the year 1998 to 2004. From the previous figure of the study, 86 cases of Karo-Kari were reported in Larkana in year 1997. Among those cases, 53 were women who had been killed brutally. Moreover, 48 population based study from the various parts of the world has been reported that 10 to $69 \%$ women physically victimized by their intimate partners; they have been battered by every 15 seconds and 3 women murdered every day in United States (2008).

At the comparison of amalgamating high prevalence to low reporting (Aftab \& Khan, 2011) enumerate that women in Pakistan without enough support experience both physical abuse and emotional violence. This leads to characterizing domestic violence as dynamic public issue in the country Pakistan. After asking married Pakistani couple, they reported that the major cause of physical and verbal abuse starts and associated with financial dispute (T.S. Ali \& BustamanteGavino, 2007). Attributing to this finding, it is crystal clear that low income and lower wealth have been remained a common predictor that causes life time abuse (T.S. Ali, Asad, \& Krantz, 2011). Generally, violence which occurs inside Pakistani homes is considered to be private matter, it does not require any outer intervention. This problem is regarded as social until and unless turns to be murder or attempt to murder (Hadi, 2018).

Though beggar women in Pakistan are terribly haunted by males not only at homes but also outside the homes, yet they are overlooked by the government authorities and majority of researchers. This research has been intended to find out domestic violence against beggar women in Hyderabad, Pakistan. It is therefore the researcher 
has selected some of the major victims of domestic violence to investigate thoroughly the causes and impacts of domestic violence. Qasimabad is one of the thickly populated talukas of Hyderabad district where the conditions of female beggars is pathetic. Every day the streets, gates of mosques and other worship places, markets, parks, main roads and other public places are full of female beggars where they can be seen begging. The physical violence inflicted on them is quite obvious from their apparent look on their faces.

\section{LITERATURE REVIEW}

The study named "Heavy Hands: An Introduction to the Crime of Intimate and Family Violence" views about domestic violence in Pakistan by saying it is a prevalent social and public health issue. The report assessed by Human Rights Watch underlines that around 30\% Pakistani women have experienced some type of domestic violence (Gosselin, 2009). The study conducted by Hansar (2007) holds a claim that 5 thousand women in Pakistan are murdered annually from Domestic Violence; while numerous others are injured or disabled. The report highlights females are attacked physically, psychologically and sexually by their intimate partners (Ajmal, 25 April 2012). Women in Pakistan are found to be lived under silent culture (National institute of population studies, 2013). Habiba (2004) has researched out that due to domestic violence many women were killed by their family members in 1998. In accordance with the estimation of Thomson Reuters Foundation, Pakistan is ranked the $3^{\text {rd }}$ most perilous nation for women population, after Afghanistan and the Democratic Republic of Congo (Lisa, 2011).

The main responsible and doer of domestic violence against women are particular members in family, like, father, brother, motherin-law, brother- in- law and intimate partner in particular (Journal of epidemiology and community wealth (Clarke, McCarthy, ÁlvarezDardet, Sogoric, Groenewegen, Groot, \& Delnoij, 2007). Moreover, Zakar et.al., (2013) have castigated the Pakistani system by maintaining there is no protecting cell for large numbers of victims of domestic violence. Similarly Haj-Yahia et.al., (2012) goes on to analyze only major cause of women's domestic violence that occurs is patriarchal family system. The report further mention law implemented authorities are found helpless for the victims and even they don't consider domestic violence as a crime. Hence, they decline to register any cases of domestic violence. 
According to world health organization report women experience the domestic violence once in their lives, the ratio of women experiencing violence is one out three (WHO, 2000; WHO, 2005). Further the discussion, women's marriage in Pakistan is reflecting some type of patriarchal structure which stresses upon women are to be subordinate under men (Qadir, Farah, deSilva, \& Khan, 2005). With this perception, it comes to image the reflection of extensive cultural structure in which men are valued to be dominated by justifying the violence in order to maintain their superiority over women (Zakar, Zakar \& Kraemer, 2013). Moreover, with regard to context of Pakistani community, this intimate partner violence has been functioned as means for maintaining the respect by using abusive language behavior so as to demonstrate wife is merely just nothing but men's subordinate (Zakar et.al., 2013). So, Physical abuse, is not a unique, it is as usual perception in culture of Pakistan,. In this regard when women are asked about abuse they frequently responded with argument a physical abuse (Aslam, Zaheer, \& Shafique, 2015).

Recently an investigation report to Pakistani women, what behavior is considered by women that causes violence against them, in this response, half of the participants went under physical violence, $8 \%$ verbal abuse as violence against them, 28\% emotional abuse (Madhani et.al., 2017). It is noted that physical abuse is on rampant rating to higher percentage with $46 \%$ to $80 \%$ this type of violence has been experienced. Moreover, generalizing the results many samples according to research predominating low wealth population with regard to Pakistani women (T.S. Ali \& Bustamante-Gavino, 2007: Sheikh 2003). Similarly, wealth is common as well as vulnerable factor causing intimate partner violence. After asking married Pakistani couple, they reported that the major cause of physical and verbal abuse starts and associated with financial dispute (T.S. Ali \& Bustamante-Gavino, 2007). Attributing to this finding, it is crystal clear that low income and lower wealth have been remained a common predictor that cause life time abuse (T.S. Ali, Asad, \& Krantz, 2011). In this perception (Zakar et.al., 2016) states that lower wealth leads to higher vulnerability which suggests that, it is common to experience intimate partner violence and inadequate to receive a proper care. A few studies examination in Pakistani sample regarding age group, it is found by one study that older women seem at high risk in their life time experiencing a heinous abuse as compare to younger women, it 
means that older she goes more abuse she experiences (T.S. Ali et.al., 2011). So, both frequency and magnitude regarding violence against women needs as well as demands for helping women, unfortunately, there seems no social workers or any other psychologists that can help each individual (Fernandez, 2012). Additionally, it is extrapolated from "Cross-Cultural Examination of Domestic Violence in China and Pakistan" study that only few women get shelters in the nation and they have narrow escape to save themselves from violent circumstances (Hansar, 2007).

Lisa (2004), an Associate Professor at the University of California, delineates domestic violence against Pakistani female as "endemic in all social spheres". Masood (2003) have conducted an observational survey from 218 women admitted in the Gynecology wards of three Pakistani hospitals. Among them 97\% participants have recorded their interviews that they have been experienced some type of abuse. The study finding further reveals the abuse ranges from verbal or menace to beating or forced/non-consensual sex. A study published in European Journal of Public Health estimates 50 percent married females in Pakistan have encountered sexual abuse and 90 percent have been mentally assaulted (Nasrullah, 2009). Zakar et.al., (2013) affirmed these insights by asserting Pakistani houses have high percentages of violence against women. Similar claim maintained by the United Nation's study Violence against Women: Mission to Pakistan and Afghanistan that the ratio of domestic violence against women is significantly high in Pakistan, but accurate proportion of violence on this population is hard to get (2000).

\section{RESEARCH OBJECTIVES}

- To find out the causes of domestic violence against female beggars in region Qasimabad Hyderabad.

- To explore and to understand the impacts of domestic violence on the lives of female beggars

- To explore whether female beggars are aware of health consequences.

\section{RESEARCH QUESTIONS}

- What are the causes of domestic violence?

- Are you aware regarding the consequences of domestic violence and its impacts on your life? 


\section{RESEARCH METHOD (QUALITATIVE)}

This study is based on exploratory research containing qualitative research technique. In this regards, the collection of data had been done through Focused Group Discussion (FGDs). The (FGDs) language was not only in Urdu, Sindhi but also in Siraki as well, after that it was translated into English Language. The perfection of data was brought under observation while having had translation. FGDs were recorded by J-5 mobile recorder, after translating they were brought into QSR NVIVO-10 software for analyses.

\section{SAMPLING DESIGN}

10 Cases of female beggars have been opted to focus research and they were identified through snow ball sampling technique.

TABLE-1

\section{STUDY PARTICIPANTS}

Detail of 10 female Baggers, Two of them took part in 02 FGDs with their social background.

\begin{tabular}{|l|l|l|l|l|}
\hline Number of Participants & Age & Gender & Education & Profession \\
\hline 1 & 26 & Female & 3 class & Beggary \\
\hline 2 & 31 & Female & Nil & Beggary \\
\hline 3 & 29 & Female & 5 class & Beggary \\
\hline 4 & 43 & Female & Nil & Beggary \\
\hline 5 & 49 & Female & Nil & Beggary \\
\hline 6 & 39 & Female & Nil & Beggary \\
\hline 7 & 41 & Female & 2 class & Beggary \\
\hline 8 & 38 & Female & Nil & Beggary \\
\hline 9 & 30 & Female & Nil & Beggary \\
\hline 10 & 27 & Female & 5 class & Beggary \\
\hline
\end{tabular}

\section{DATA COLLECTION}

02 FGDs had been conducted during the month of March 2018 to May 2018 each FGDs contains 5 members. 
TABLE-2

FGDS

Detail of Focused Group Discussion

\begin{tabular}{|l|l|l|l|}
\hline Discussion ID & Location & Total Participants & Audio(Timing) \\
\hline FGD-I & $\begin{array}{l}\text { Qasimabad } \\
\text { Taluka }\end{array}$ & 05 & 40 minutes \\
\hline FGD-II & $\begin{array}{l}\text { Qasimabad } \\
\text { Taluka }\end{array}$ & 05 & 57 minutes \\
\hline
\end{tabular}

\section{LOCALE OF THE STUDY}

Universe Qasimabad Hyderabad district.

\section{ETHICAL RULES}

Ethical rules were followed strictly for this research. For this purpose, respondents' willingness for the interviews was given priority.

\section{RESULTS}

Age: The mean age respondents was $38.25 \&$ SD 9.87

\section{Causes of Domestic Violence Against Female Beggars}

While conducting interviews and a long discussion held in between interviewer and respondents it came to conclusion that most of the respondents were well known regarding the causes of domestic violence but few of them were unknown. From the above research, it has been concluded that there are various causes of domestic violence which prevailed against female beggars living in Qasimabad. The causes likewise, rising poverty, rising illiteracy, lack of earning livelihood, drug addiction, population explosion.

\section{Rising Poverty}

After conducting the interviews from the victimized female beggars, some of the respondents told that rising poverty was the main cause which compelled them to beg through door to door for filling up the belly of their family. In this way, male partners forced them to provide money to feed the family if they did not bring they would be tortured harshly. This resulted an unbelievable physical beating on the body which they showed during discussion (Participant 1 and 3 FGD$1)$. 


\section{Rising Illiteracy}

Another cause which was pointed out by the respondents during interviews was illiteracy which caused them to beg. Many of them responded that their male partners were unable to do work and rest of them felt dishonored in begging that's why they forced them for earning money to run home. If they denied they would be beaten. Finally they left their homes for bringing money to leave home for begging in the streets or anywhere else. (Participant 1, 4 and 5 FGD-1)

\section{Lack of Earning Livelihood}

This class is extremely violated not only at home but also outside the home. They notified that their male partners were physically handicapped and due to extreme poverty they were unable to survive and they did not have a single morsel to eat. Therefore, it was compellation which insisted them to beg for earning livelihood if they did not arrange a meal of the day, they would suffer a lot home.(Participant 2 and 3 FGD-1)

\section{Drug Addiction}

During consecutive interviews, the respondents stated that mostly the male partners were addicted using drug every day. On that the respondents clearly justified by stating that male partners beat them physically in order to earn money for providing drug. (Participant 7 FGD.2).

\section{Population Explosion}

Further the discussion, this came to evidence that population explosion remained a heinous cause of domestic violence. Huge family was unable to survive it needed some resources to live so the female beggars being uneducated went in street to beg for the sake of survival for feeding the belly of the family. Evidently they showed bruised on the face and body that if they did not earn money in a whole day they were physically beaten by sticks. (Participant 10 FGD-2)

\section{IMPACTS OF DOMESTIC VIOLENCE}

Physical and Mental Impacts: Domestic violence is a curse that destroys women physically and mentally. The most affected class of domestic violence is female beggars. Their physical and mental impacts are narrated below. 
According to respondent 2, 1 and 5 (FGD-1) they had been victims of physical violence, in this way they showed their physical evidences on their bodies. One respondent was lame of one leg and another was broken hand and third one was badly bruised. Even the worst case was interviewed; the respondent (give reference) narrated a painful story that due to her father in law beating, she lost her 4 months baby.

Mental health issues are also the result of domestic violence. It is observed in respondents that they are trapped in mental disorder. The common health issue was depression that was noted in them. One respondent revealed that she was hyper-tension. The other respondent had said she attempted suicide a couple of times due to the mental stress from male family members.

\section{LIMITATIONS OF THE STUDY}

The research is based on 02 FGDs with the help of 10 respondents only that are insufficient for in-depth understanding of the causes behind the domestic violence against female baggers. So, results cannot be generalized further.

\section{CONCLUSION}

Domestic violence against female beggars seems order of the day after the long research conducted in taluka Qasimabad. While conducting interviews the response of the respondents portraits a grim picture within the Qasimabad universe in which researcher conducted the research.

Moreover to say this study in sum up concludes an unforgettable and very pathetic condition of female beggars of Qasimabad. It demands an immediate effective measures as well as response from the Government and the social scientists, that they do not only address the problem regarding domestic violence against female beggars but also ought to be resolved this menace of society.

\section{REFRENCES}

Aslam, S. K., Zaheer, S., \& Shafique, K. (2015). Is spousal violence being "vertically transmitted" through victims? Findings from the Pakistan Demographic and Health Survey 2012-13. PLoS ONE, 10(6), e0129790.

Aftab, S., \& Kahn, A. (2011). Women surviving under the menace of domestic violence. 
Ali, T. S., Asad, N., Mogren, I., \& Krantz, G. (2011). Intimate partner violence in urban Pakistan: Prevalence, frequency, and risk factors. International Journal of Women's Health, 3, 105-115.

Ali, T. S., \& Bustamante-Gavino, I. (2007). Prevalence of and reasons for domestic violence among women from low socioeconomic communities of Karachi. Eastern Mediterranean Health Journal, 13(6), 1417-1426.

Bhatti, A. G., Khoso, A. A., \& Buriro, A. A. (2012). Attitudes of Working and Non-Working Women about Domestic Violence: An Analytic Study of Hyderabad. The Women-Annual Research Journal of Gender Studies, 4.

Bibi, S., Ashfaq, S., Shaikh, F., \& Qureshi, P. M. A. (2014). Prevalence instigating factors and help seeking behavior of physical domestic violence among married women of Hyderabad Sindh. Pakistan Journal of Medical Sciences, 30(1), 122.

Bunch, T. (2005). Ending men's violence against women. Retrieved on 10 September 2011 from The National Resource Centre on Domestic Violence.

Clarke, A., McCarthy, M., Álvarez-Dardet, C., Sogoric, S., Groenewegen, P., Groot, W., \& Delnoij, D. (2007). New directions in European public health research: Report of a workshop. Journal of Epidemiology \& Community Health, 61(3), 194-197.

Esquivel-Santoveña, Esteban Eugenio; Lambert, Teri L.; Hamel, John (January 2013). Partner abuse worldwide (PDF). Partner Abuse. 4 (1):6-75. doi:10.1891/1946-6560.4.1.6.

Fawole, O. I., Asekun-Olarinmoye, E. O., \& Osungbade, K. O. (2013). Are very poor women more vulnerable to violence against women? comparison of experiences of female beggars with homemakers in an urban slum settlement in Ibadan, Nigeria. Journal of Health Care for the Poor and Underserved, 24(4), 1460-1473.

Fernández, A.M. (2012). Gender violence: femicides in Argentina. Interdisciplinary Journal of Family Studies, XVII(2). Padova: Padova University Press.

Fikree, F.F. and O. Pasha (2004). Role of gender in health disparity: The South Asian context. British Medical Journal, 328, 823-26.

García-Moreno, Claudia; Stöckl, Heidi (2013). "Protection of sexual and reproductive health rights: Addressing violence against women", in Grodin, Michael A.; Tarantola, Daniel; Annas, George J.; et.al., Health and human rights in a changing world, Routledge, pp.780-781. ISBN 9781136688638

Gosselin, Denise Kindschi (2009). Heavy Hands: An Introduction to the Crime of Intimate and Family Violence (4th ed.). Prentice Hall. p. 13. ISBN 9780136139034.

Hadi, A. (2018). Intimate Partner Violence and Its Under-Reporting in Pakistan. European Journal of Social Sciences Education and Research, 12(1), 254-260. 
Hajjar, Lisa (2004). "Domestic Violence and Sharía: A Comparative Study of Muslim Societies in the Middle East, Africa and Asia". In Lynn Welchman. Women's Rights and Islamic Family Law: Perspectives on Reform. Zed Books. p.265. ISBN 978-1842770955.

Hansar, Robert D. (2007). "Cross-Cultural Examination of Domestic Violence in China and Pakistan". In Nicky Ali Jackson. Encyclopedia of Domestic Violence (1st ed.). Routledge. p.211. ISBN 978-0415969680.

Haj-Yahia, M. M., Wilson, R. M., \& Naqvi, S. A. M. (2012). Justification, perception of severity and harm, and criminalization of wife abuse in the Palestinian society. Journal of Interpersonal Violence, 27, 1932-1958.

Iqbal, M., \& Fatmi, Z. (2018). Prevalence of emotional and physical intimate partner violence among married women in Pakistan. Journal of Interpersonal Violence, 0886260518796523.

McQuigg, Ronagh J.A. (2011), "Potential problems for the effectiveness of international human rights law as regards domestic violence", in McQuigg, Ronagh J.A., International human rights law and domestic violence: The effectiveness of international human rights law, Oxford New York: Taylor \& Francis, p.13, ISBN 9781136742088

National Institute of Population Studies. (2013). Pakistan Demographic and Health Survey. Retrieved from: https://dhsprogram.com/pubs /pdf/fr290/fr290.pdf

Nasrullah, Muazzam; Haqqi, Sobia; Cummings, Kristin (2009). The epidemiological patterns of honour killing of women in Pakistan. European Journal of Public Health, 19 (2),193-197. doi:10.1093/eurpub/ ckp021. PMID 19286837.

Patel, R. (2003). Woman versus man: Socio-legal gender inequality in Pakistan. Oxford University Press.

Qadir, F., de Silva, P., Prince, M., \& Khan, M. (2005). Marital satisfaction in Pakistan: A pilot investigation. Sexual and Relationship Therapy, 20, 195209.

Shaikh, Masood Ali (2003). Is domestic violence endemic in Pakistan: perspective from Pakistani Wives (PDF). Pakistan Journal of Medical Sciences, 19 (1), 23-28.

World Health Organization. (2005). Addressing violence against women and achieving the Millennium Development Goals.

World Health Organization. (2000). Women of South-East Asia: A health profile. New Delhi: WHO, South-East Asia Regional Office.

Zakar, Rubeena; Zakar, Muhammad; Mikolajczyk, Rafael; Kraemer, Alexander (2013). "Spousal Violence Against Women and Its Association with Women's Mental Health in Pakistan". Health Care for Women International, 34 (9):795-813. doi:10.1080/07399332.2013.794462. PMID 23790086 . 
Zaman, Habiba (2004). Suad Joseph; Afsaneh Najmabad, (eds.) Family, Law and Politics: Encyclopedia of Women and Islamic Cultures: 2. Brill. p.124. ISBN 978-9004128187.

Zakar, R., Zakar, M. Z., \& Kraemer, A. (2013). Men's beliefs and attitudes toward intimate partner violence against women in Pakistan. Violence Against Women, 19, 246-268.

Anderson, Lisa (15 June 2011). Trustlaw Poll: Afghanistan is most dangerous country for women. Thomson Reuters Foundation. Retrieved 31 July 2012. Concannon, Diana (July 11, 2013). Kidnapping: An Investigator's Guide. Newnes. p.30. ISBN 978-0123740311.

Ajmal, Umer Bin (25 April 2012). Domestic violence. Dawn. Retrieved 28 July 2012.

Strong, Bryan; DeVault, Christine; Cohen, Theodore (February 16, 2010). The Marriage and Family Experience: Intimate Relationships in a Changing Society. Cengage Learning. p. 447. ISBN 978-1133597469. 